\title{
Profil Kemampuan Pemecahan Masalah PISA pada Konten Change and Relationship Berdasarkan Taksonomi SOLO
}

\author{
Nanda Putri Wahyuni ${ }^{1}$, Masriyah ${ }^{2}$ \\ 1,2 Program Studi Pendidikan Matematika, Fakultas Matematika dan Ilmu Pengetahuan Alam, Universitas Negeri Surabaya, \\ Jl. Ketintang, Gayungan, Surabaya, Jawa Timur, Indonesia \\ nanda.17030174043@mhs.unesa.ac.id
}

\begin{abstract}
Students' mathematical problem-solving abilities have different levels, especially in the context of PISA which is rarely found in general learning in schools. To measure the level of problem-solving ability, we can use a method called the SOLO Taxonomy (Structure of the Observed Learning Outcome). The aim of this study was to describe PISA problem-solving ability in change and relationship content for students with high, medium, and low mathematical abilities based on the SOLO taxonomy. The research method used in this research is qualitative research. The subject of this study were 3 students from class IX, which consisted of students with high, medium, and low mathematical abilities. The data collection method was collected from test methods, and interviews. Then the research instruments used were the Mathematical Ability Test, Problem-solving Test, and interview guidelines. The result of this study indicated that PISA problem-solving abilities on change and relationship content in students with high mathematical abilities were able to reach the extended abstract level, students with moderate mathematical abilities were able to reach the multistructural level, and students with low mathematical abilities are able to reach the unistructural level.
\end{abstract}

Keywords: PISA, mathematical abilities, SOLO taxonomy

\begin{abstract}
Abstrak
Kemampuan pemecahan masalah matematika siswa memiliki tingkat yang berbeda-beda, terlebih pada konteks PISA yang jarang ditemui dalam pembelajaran umum di sekolah. Untuk mengukur tingkat kemampuan pemecahan masalah tersebut dapat menggunakan suatu metode yang disebut dengan Taksonomi SOLO (Structure of the Observed Learning Outcome). Penelitian ini bertujuan untuk mendeskripsikan kemampuan pemecahan masalah PISA konten change and relationship pada siswa yang memiliki kemampuan matematis tinggi, sedang, dan rendah berdasarkan Taksonomi SOLO. Metode penelitian yang digunakan dalam penelitian ini adalah penelitian kualitatif. Subjek penelitian ini adalah 3 siswa dari kelas IX, yang terdiri dari siswa dengan kemampuan matematika tinggi, sedang, dan rendah. Metode pengumpulan data dilakukan dengan metode tes, dan wawancara. Kemudian instrumen penelitian yang digunakan yaitu Tes Kemampuan Matematika (TKM), Tes Pemecahan Masalah (TPM), dan pedoman wawancara. Hasil dari penelitian ini menunjukkan bahwa kemampuan pemecahan masalah PISA konten change and relationship pada siswa dengan kemampuan matematika tinggi mampu mencapai level extended abstract, siswa dengan kemampuan matematika sedang mampu mencapai level multistructural, dan siswa dengan kemampuan matematika rendah mencapai level unistructural.
\end{abstract}

Kata kunci: PISA, kemampuan matematika, taksonomi SOLO

Copyright (c) 2021 Nanda Putri Wahyuni, Masriyah

Corresponding author: Nanda Putri Wahyuni

Email Address: nanda.17030174043@ mhs.unesa.ac.id (Jl. Ketintang, Gayungan, Surabaya, Jawa Timur, Indonesia)

Received 16 July 2021, Accepted 23 July 2021, Published 10 August 2021

\section{PENDAHULUAN}

Dalam kehidupan sehari-hari banyak ditemui masalah yang muncul tiba-tiba dan menuntut setiap individu untuk dapat memecahkan masalah tersebut dengan baik tanpa menghindarinya. Begitu pula dalam pembelajaran matematika di sekolah. Pemecahan masalah sendiri merupakan proses dalam merespon atau menerapkan pengetahuan secara terarah untuk menemukan solusi dari suatu situasi baru yang hasilnya belum pasti. Hal ini sejalan dengan yang diungkapkan Siswono (Siswono, 2008) mengenai pengertian pemecahan masalah, yaitu "pemecahan masalah merupakan suatu proses atau upaya individu untuk 
Profil Kemampuan Pemecahan Masalah PISA pada Konten Change and Relationship Berdasarkan Taksonomi SOLO, Nanda Putri Wahyuni, Masriyah

merespon atau mengatasi halangan atau kendala ketika suatu jawaban atau metode jawaban belum tampak jelas". Pemecahan masalah dalam matematika berperan penting dalam pelaksanaan pembelajaran matematika. Hal ini sejalan dengan yang dijelaskan oleh NCTM (NCTM, 2000) bahwa "problem-solving is an integral part of all mathematics learning". Maksudnya bahwa pemecahan masalah dalam hubungannya dengan pembelajaran matematika merupakan bagian integral dalam semua aspek pembelajaran matematika. Sehingga dalam melaksanakan pembelajaran matematika perlu dibiasakan untuk memecahkan masalah yang berhubungan dengan matematika terutama dalam konteks kehidupan seharihari atau masalah kontekstual.

Kemampuan pemecahan masalah siswa berbeda-beda bergantung dari kemampuan siswa tersebut dalam menyelesaikan masalah matematika atau biasa disebut kemampuan matematika. Hal ini sesuai dengan yang diungkapkan oleh Isroil dkk (Isroil et al., 2017) bahwa terdapat perbedaan berpikir pada siswa berkemampuan matematika tinggi, sedang, dan rendah dalam menerima dan mengolah informasi yang diterima.

Sehubungan dengan masalah kontekstual dalam matematika, terdapat suatu organisasi khusus yang mengembangkan pelatihan atau tes yang melibatkan pemecahan masalah berkaitan dengan konteks dalam dunia nyata, yang dikenal dengan nama PISA. PISA merupakan sebuah riset yang bertujuan untuk menilai kemampuan siswa dalam menyelesaikan masalah dalam konteks kehidupan nyata. Program ini diselenggarakan OECD dan mulai dilaksanakan pada tahun 2000. Dalam hal ini, PISA tidak hanya menilai kemampuan siswa dalam menyelesaikan masalah, tetapi juga menilai kemampuan siswa dalam mengeksplorasi pengetahuannya lebih dalam pada konteks yang asing. (OECD, 2019)

Dengan adanya soal PISA yang terkenal dengan penggunaan konteks asing atau tidak familiar dalam soal-soalnya, tingkat kesulitan dalam memecahkan masalah pun juga lebih tinggi. Seifi (Seifi et al., 2012) mengungkapkan bahwa penyebab kesulitan siswa dalam menyelesaikan masalah adalah kesulitan teks, penggunaan strategi yang tidak sesuai, dan adanya konteks-konteks yang tidak familier dalam permasalahan.

Berdasarkan hasil studi PISA 2018, peringkat Indonesia pada PISA Matematika berada di peringkat 72 dari 78 negara yang berpartisipasi (Schleicher, 2019). Hasil tersebut masih jauh dari yang diharapkan. Apalagi jika melihat dari skor rata-rata siswa Indonesia yaitu dengan skor 380 yang berada di level 1, dan itu pun masih menempati peringkat ke-17 dari 20 negara yang berada di level yang sama. Hal tersebut menunjukkan bahwa kemampuan matematis siswa dalam memecahkan masalah matematika di Indonesia masih tergolong rendah dibandingkan dengan negara lain, bahkan negara tetangga seperti Singapura, Malaysia, Thailand, dan sebagainya.

PISA membagi konten matematika menjadi 4 kategori, salah satunya adalah konten perubahan dan hubungan (change and relationship). Konten change and relationship merupakan perwujudan pengetahuan matematika yang melibatkan perubahan, seperti hubungan fungsional dan keterkaitan antar variabelnya (OECD, 2019). Konten change and relationship dalam kurikulum matematika berhubungan dengan materi fungsi dan aljabar. Berdasarkan hasil PISA pada tahun 2003, Stacey dalam (Hasibuan et al., 2019) 
mengemukakan bahwa Indonesia memperoleh skor terendah pada konten change and relationship. Sedangkan pada hasil PISA tahun 2012, Indonesia menempati urutan ke-4 terbawah dari 65 negara dengan skor rata-rata 364 dalam konten change and relationship (NCES, 2013). Hal ini mengindikasikan bahwa pokok bahasan fungsi dan aljabar dalam kurikulum Indonesia merupakan konten yang cukup sulit untuk dipecahkan oleh siswa-siswa di Indonesia.

Ada banyak hal yang mempengaruhi rendahnya tingkat kemampuan siswa dalam aljabar, seperti kesulitan dalam memahami konsep aljabar, simbol, maupun perhitungan. Hal ini sesuai dengan hasil penelitian yang dilakukan oleh Sugiarti bahwa kesulitan siswa dalam memecahkan soal aljabar berkaitan dengan konsep (variabel dan konstanta) dan prinsip (penjumlahan, pengurangan, dll) (Sugiarti, 2018). terlepas dari kesulitan konsep, simbol, dan perhitungan, siswa cenderung sulit untuk memilih informasi yang sesuai untuk menyelesaikan permasalahan di soal. Siswa lebih cenderung menggunakan seluruh informasi seperti angka yang diberikan dalam soal tanpa memikirkan keterikatannya dengan permasalahan yang ditanyakan di soal untuk menyelesaikan masalah (Wijaya et al., 2014). Selain itu, jika siswa sudah kesulitan dalam memecahkan soal aljabar yang sering dijumpai di sekolah, apalagi masalah kontekstual di sekitar yang jarang ditemui di sekolah. Pokok bahasan aljabar juga merupakan salah satu materi yang cukup sulit untuk dipahami. Hal ini sesuai dengan pendapat Jupri yang menyatakan bahwa aljabar merupakan konsep yang sulit untuk dipelajari maupun diajarkan (Jupri et al., 2014).

Dalam mengukur kemampuan siswa, terdapat berbagai macam metode, salah satunya dengan menggunakan Taksonomi SOLO. Biggs and Collis menyatakan bahwa kemampuan hasil belajar siswa pada tahap kognitif dimulai dari tahap yang sederhana kemudian meningkat sampai ke tahap abstrak (Biggs \& Collis, 1982). Teori ini dikenal dengan istilah SOLO (Structure of the Observed Learning Outcome). Taksonomi SOLO digunakan untuk mengukur dan mengklasifikasikan kemampuan siswa dalam merespon suatu hal menjadi lima level dan hierarkis, dimulai dari yang sederhana ke abstrak yaitu level prestructural, unistructural, multistructural, relational, dan extended abstract. Selain itu, taksonomi SOLO juga dapat menggambarkan bagaimana struktur kompleksitas kognitif atau respon siswa dari level yang ada (Putri \& Manoy, 2013).

Tujuan dari penggunaan Taksonomi SOLO di penelitian ini yaitu untuk mengukur kemampuan pemecahan masalah siswa. Taksonomi SOLO dapat menjadi salah satu cara yang efektif dan sistematis untuk memahami dan mendeskripsikan kemampuan siswa dalam memecahkan masalah yang diberikan. Hal ini sesuai dengan pernyataan Kuswana dalam (Silwana et al., 2021) bahwa tujuan dari taksonomi SOLO adalah untuk membantu memberikan langkah yang sistematis mengenai bagaimana cara untuk mendeskripsikan dan menganalisis bagaimana siswa berkembang secara struktual ketika menghadapi berbagai masalah. Taksonomi SOLO sendiri diklasifikasikan menjadi lima level. Lebih jelasnya, berikut disajikan tabel mengenai indikator kelima level Taksonomi SOLO dalam penelitian ini. 
Profil Kemampuan Pemecahan Masalah PISA pada Konten Change and Relationship Berdasarkan Taksonomi SOLO, Nanda

Tabel 1. Level Taksonomi SOLO

\begin{tabular}{|l|l|c|}
\hline $\begin{array}{c}\text { Level Taksonomi } \\
\text { SOLO }\end{array}$ & \multicolumn{1}{|c|}{ Indikator } & Kode \\
\hline Prestructural & $\begin{array}{l}\text { Tidak memahami informasi pada soal sehingga tidak dapat } \\
\text { menyelesaikan masalah }\end{array}$ & PS \\
\hline Unistructural & $\begin{array}{l}\text { Mampu menggunakan satu informasi atau strategi untuk } \\
\text { menyelesaikan masalah }\end{array}$ & US \\
\hline Multistructural & $\begin{array}{l}\text { Mampu menggunakan beberapa informasi dan strategi } \\
\text { penyelesaian namun belum bisa menghubungkannya, atau } \\
\text { mampu menghubungkan namun gagal menyelesaikan masalah }\end{array}$ & MS \\
\hline Relational & $\begin{array}{l}\text { Mampu memadukan informasi-informasi berbeda untuk } \\
\text { menyelesaikan permasalahan namun belum bisa melakukan } \\
\text { generalisasi }\end{array}$ & RT \\
\hline Extended Abstract & $\begin{array}{l}\text { Mampu memadukan informasi-informasi berbeda dan mampu } \\
\text { melakukan generalisasi untuk diterapkan pada konteks yang } \\
\text { lebih luas }\end{array}$ & EA \\
\hline
\end{tabular}

(Biggs \& Collis, 1982)

Ketika siswa dihadapkan pada masalah, khususnya pada masalah matematika, kemampuan siswa tersebut dalam menyelesaikan masalah dapat dilihat dari respon yang mereka berikan. Seorang guru tidak dapat melihat langsung kemampuan siswa dalam menyelesaikan masalah melalui proses berpikir yang sedang terjadi, akan tetapi guru dapat mengetahui kemampuan itu dari kualitas respon-respon yang diberikan (Faisal \& Maryulianty, 2019). Berdasarkan hal itu, maka salah satu cara yang tepat untuk mengukur dan menilai tingkat jawaban atau respon siswa dalam memecahkan masalah matematika yaitu dengan taksonomi SOLO.

Berdasarkan dari uraian di atas, kemampuan matematika siswa sangat berkaitan dengan tingkat keberhasilan dalam menyelesaikan masalah matematika. Selain itu untuk mengukur tingkat kemampuan pemecahan masalah siswa dapat menggunakan suatu alat, salah satunya dengan menggunakan Taksonomi SOLO. Terdapat beberapa penelitian yang relevan terkait pemecahan masalah berdasarkan Taksonomi SOLO. Salah satunya adalah penelitian yang dilakukan oleh Faisal mengenai analisis tingkat kemampuan siswa dalam menyelesaikan soal cerita sistem persamaan linear tiga variabel berdasarkan taksonomi SOLO (Faisal \& Maryulianty, 2019). Hasil dari penelitian ini menunjukkan bahwa tingkat kemampuan siswa yang memiliki kemampuan tinggi mampu mencapai tingkat extended abstract, siswa yang memiliki kemampuan sedang mampu mencapai tingkatan atau level multistruktural, dan siswa yang memiliki kemampuan rendah berada pada tingkat unistruktural. Perbedaan penelitian ini dengan penelitian oleh Faisal yaitu peneliti menggunakan soal yang berdasarkan konteks permasalahan PISA sedangkan penelitian Faisal menggunakan pokok bahasan sistem persamaan linear tiga variabel. Selain itu, pemilihan jenjang pendidikan, indikator penelitian, tata cara pemilihan subjek, serta teknik analisis data yang digunakan dalam penelitian ini juga berbeda dengan penelitian yang dilakukan Faisal. Penelitian yang dilakukan oleh Faisal tidak menjelaskan secara rinci mengenai cara pengambilan subjek utama untuk mengukur respon mereka dalam menyelesaikan soal. Tes diberikan kepada semua siswa di kelas, namun yang dipilih hanya tiga siswa, tanpa penjelasan yang lebih rinci. Sehingga dalam penelitian ini menggunakan metode yang jelas dalam 
memilih subjek penelitian. Selain itu, perbedaan pemilihan jenjang SMP dan SMA juga memberikan hasil yang berbeda. Apalagi dengan mengambil konteks permasalahan PISA yang dikenal lebih sulit daripada soal pada materi yang biasa diajarkan di sekolah.

Kemudian penelitian lain yang relevan adalah penelitian oleh Marisa yang meneliti tentang kesalahan siswa dalam menyelesaikan soal operasi aljabar berdasarkan taksonomi SOLO (Marisa et al., 2020). Hasil dari penelitian ini yaitu siswa dalam menyelesaikan soal operasi Aljabar, baik siswa yang berada di level prastruktural, unistruktural, multistruktural, maupun relasional, melakukan kesalahan pada tingkatan yang berbeda-beda sesuai jenis kesalahan yang dilakukan masing-masing siswa. Perbedaan penelitian yang dilakukan peneliti dengan penelitian Marisa terdapat pada penggunaan konteks PISA sebagai pokok permasalahan dalam pembuatan soal, tujuan penelitian, pemilihan subjek, indikator penelitian, dan teknik analisis data yang digunakan dalam penelitian.

Berdasarkan latar belakang di atas, hal yang menjadi ketertarikan peneliti adalah melihat bagaimana profil kemampuan pemecahan masalah PISA konten change and relationship pada siswa yang memiliki kemampuan matematis tinggi, sedang, dan rendah berdasarkan Taksonomi SOLO. Sehingga tujuan dari penelitian ini adalah mendeskripsikan kemampuan pemecahan masalah PISA konten change and relationship pada siswa yang memiliki kemampuan matematis tinggi, sedang, dan rendah berdasarkan Taksonomi SOLO. Penelitian ini diharapkan dapat memberikan gambaran mengenai kemampuan pemecahan masalah PISA siswa berdasarkan Taksonomi SOLO dan dapat dijadikan sebagai bahan untuk melatih dan mengajarkan siswa agar lebih terampil dalam memecahkan masalah PISA.

\section{METODE}

Penelitian ini merupakan penelitian kualitatif. Subjek penelitian yang digunakan yaitu 3 siswa kelas IX. Ketiga siswa tersebut dipilih dengan kriteria siswa berkemampuan matematika tinggi, sedang, dan rendah berdasarkan hasil tes kemampuan matematika yang diujikan kepada seluruh siswa di kelas yang telah dipilih. Pemilihan subjek penelitian dari masing-masing kategori dipilih dengan ketentuan: kategori kemampuan tinggi dipilih siswa yang memiliki nilai tertinggi di kategorinya; kategori kemampuan sedang dipilih siswa yang memiliki nilai rata-rata di kategorinya; dan kategori kemampuan rendah dipilih siswa yang memiliki nilai terendah di kategorinya. Peneliti juga meminta pertimbangan guru bidang studi dalam memilih subyek penelitian. Kriteria pemilihan subyek mengacu pada hal berikut: (1) siswa dengan kategori kemampuan matematis tinggi, sedang, dan rendah yang mana untuk tiap kategori diambil 1 siswa, dan (2) keterbukaan dan kelancaran dalam berkomunikasi lisan berdasarkan pertimbangan dari guru matematika di sekolah tersebut. Kemudian berikut adalah kriteria untuk kategori kemampuan matematika.

Tabel 2. Kriteria Kategori Kemampuan Matematika

\begin{tabular}{|l|c|}
\hline \multicolumn{1}{|c|}{ Kategori } & Skor \\
\hline Kemampuan matematika tinggi & $85<$ skor $\leq 100$ \\
\hline Kemampuan matematika sedang & $60<$ skor $\leq 85$ \\
\hline Kemampuan matematika rendah & $0 \leq$ skor $\leq 60$ \\
\hline
\end{tabular}

(Ratri \& Setyaningsih, 2020) 
Profil Kemampuan Pemecahan Masalah PISA pada Konten Change and Relationship Berdasarkan Taksonomi SOLO, Nanda

Instrumen yang digunakan yaitu tes kemampuan matematika (TKM) berupa soal uraian yang diadaptasi dari soal UN berkaitan dengan materi fungsi dan aljabar; tes pemecahan masalah PISA (TPM) berupa soal uraian yang diadaptasi dari soal PISA pada konten change and relationship; dan pedoman wawancara. Instrument tes pemecahan masalah PISA yang digunakan di penelitian ini telah divalidasi dan disetujui untuk digunakan oleh validator. Metode pengumpulan data yaitu (1) metode tes yang digunakan untuk memperoleh data mengenai tingkat kemampuan siswa, (2) wawancara untuk menggali informasi lebih dalam mengenai data jawaban siswa dalam menyelesaikan masalah. Metode tes meliputi tes kemampuan matematika (TKM) untuk mengetahui tingkat kemampuan matematika siswa dan tes pemecahan masalah PISA (TPM) untuk mendapatkan data mengenai kemampuan siswa dalam memecahkan masalah PISA.

Teknik analisis data yang digunakan dalam penelitian ini terdapat 3 tahapan, yaitu tes kemampuan matematika, tes pemecahan masalah PISA, dan wawancara. Pada tes kemampuan matematika, hasil tes direkapitulasi dan dikategorikan ke kategori siswa berkemampuan matematika tinggi, sedang, dan rendah. Pada tes pemecahan masalah PISA, hasil tes dianalisis berdasarkan indikator Taksonomi SOLO (Tabel 1) yang telah ditentukan untuk mendeskripsikan kemampuan pemecahan masalah PISA. Kemudian pada tahap wawancara terdapat tiga tahap analisis, yaitu (1) reduksi data, dilakukan saat data hasil wawancara telah selesai dilaksanakan, kemudian dari data-data kasar dipilah-pilah dan menghilangkan data-data yang tidak diperlukan (2) penyajian data, disusun dari hasil tes dan wawancara kemudian dikaitkan antar jawaban dengan hasil wawancara untuk mendapat kesimpulan, dan (3) penarikan kesimpulan, didasarkan pada hasil dari tahap-tahap sebelumnya untuk melihat level pemecahan masalah PISA pada konten change and relationship berdasarkan Taksonomi SOLO.

\section{HASIL DAN DISKUSI}

Berdasarkan hasil tes kemampuan matematika pada 19 siswa di kelas IX SMPN 1 Tarokan, terdapat 5 siswa dengan kemampuan rendah, 10 siswa dengan kemampuan sedang, dan 4 siswa dengan kemampuan tinggi. Masing-masing dari kategori kemampuan matematika tersebut dipilih masing-masing 1 siswa sebagai subjek penelitian. Instrumen tes yang digunakan untuk tes kemampuan matematika adalah sebagai berikut.
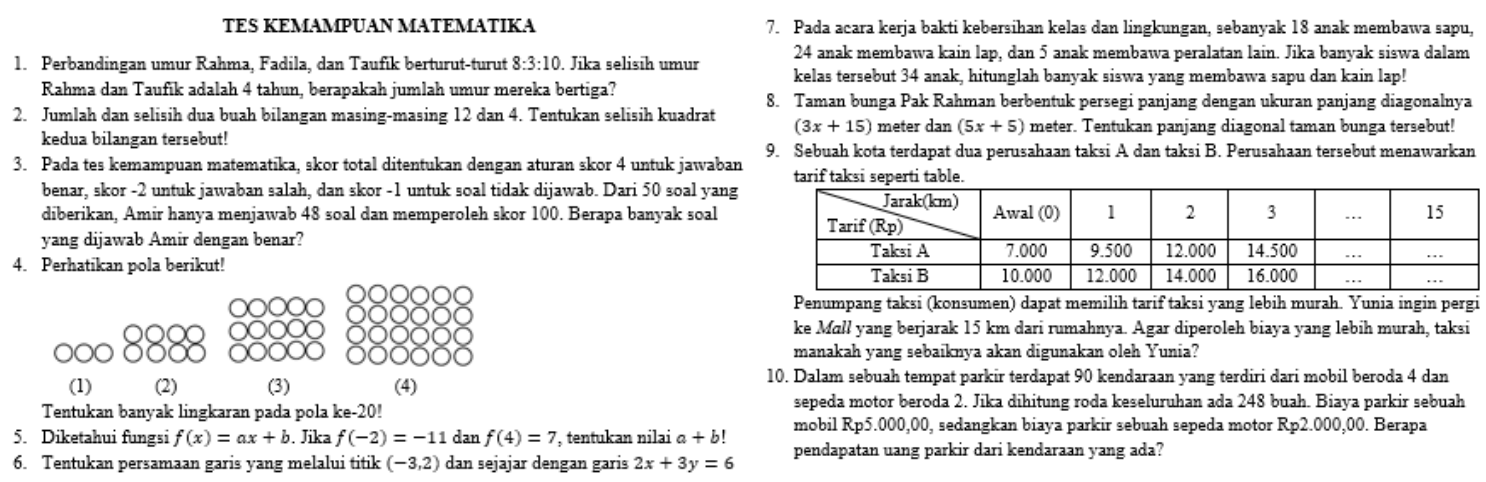

Gambar 1. Instrumen Tes Kemampuan Matematika 
Setelah melalui pertimbangan dengan guru matematika di sekolah dan hasil tes, dipilihlah 3 subjek penelitian yang memenuhi kriteria. Subjek penelitian yang telah terpilih tersebut adalah IA (kemampuan matematika tinggi dengan skor 95), KC (kemampuan matematika sedang dengan skor 70), dan MV (kemampuan matematika rendah dengan skor 25).

Agar mempermudah menganalisis data penelitian, peneliti menggunakan pengkodean nama-nama subjek dengan kode. Untuk siswa dengan kemampuan matematika tinggi menggunakan kode "ST", siswa dengan kemampuan matematika sedang menggunakan kode "SS", dan siswa dengan kemampuan matematika rendah menggunakan kode "SR". Sehingga dalam hal ini, subjek IA yang merupakan siswa dengan kemampuan matematika tinggi diberi kode sebagai subjek ST, subjek KC yang merupakan siswa dengan kemampuan matematika sedang diberi kode sebagai subjek SS, dan subjek MV yang merupakan siswa dengan kemampuan matematika rendah diberi kode sebagai subjek SR.

Ketiga subjek penelitian yang dipilih diberikan soal tes pemecahan masalah PISA untuk mendapatkan data mengenai kemampuan pemecahan masalah PISA pada konten change and relationship pada siswa berkemampuan matematis tinggi, sedang, dan rendah berdasarkan Taksonomi SOLO. Instrumen soal tes pemecahan masalah PISA yang digunakan yaitu sebagai berikut.

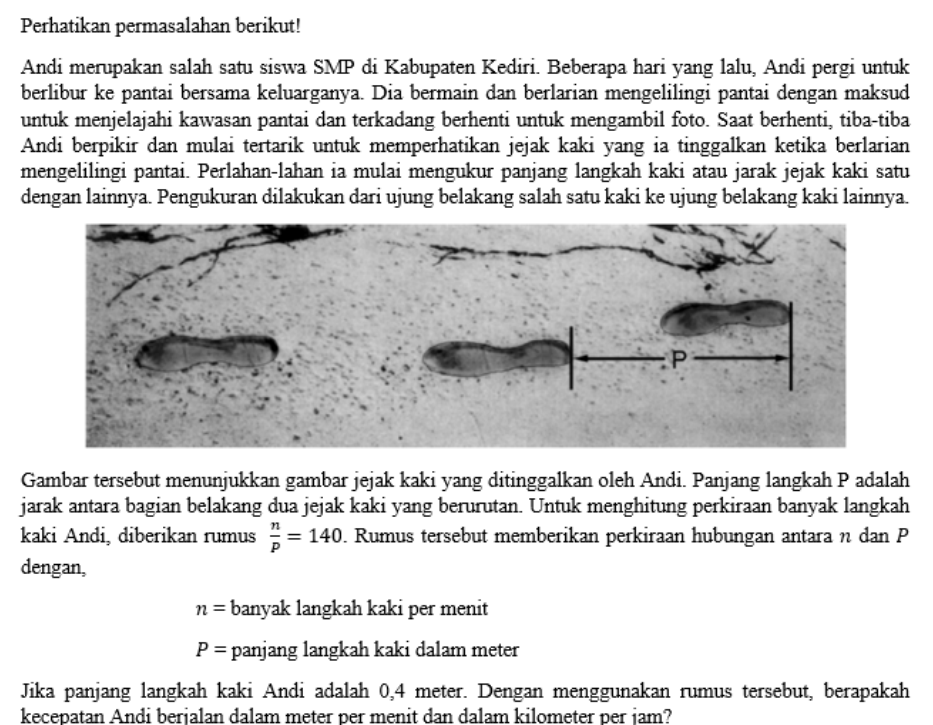

kecepatan Andi berjalan dalam meter per menit dan dalam kilometer per jam?

Gambar 2. Instrumen Tes Pemecahan Masalah

Berikut analisis jawaban dari tiap subjek secara terperinci:

\section{Analisis Data Subjek ST (Subjek Kemampuan Tinggi)}

Berdasarkan hasil jawaban pada Gambar 3 berikut, ST mampu memahami soal yang diberikan. Hal ini dapat diketahui dari jawaban ST yang mampu menyebutkan apa saja diketahui dalam soal yaitu panjang langkah kaki Andi $(P=0,4 \mathrm{~m})$ dan rumus yang diberikan $\frac{n}{P}=140$ dan ditanyakan dari soal yaitu kecepatan berjalan dalam meter per menit dan kilometer per jam (ST.PS).

Kemudian strategi yang digunakan dalam menyelesaikan masalah juga terstruktur dengan rapi. Subjek mampu menyelesaikan masalah dengan memadukan beberapa informasi, baik dari soal maupun dari 
Profil Kemampuan Pemecahan Masalah PISA pada Konten Change and Relationship Berdasarkan Taksonomi SOLO, Nanda Putri Wahyuni, Masriyah

pengetahuan yang sudah dimiliki sebelumnya. Ketika mencari langkah kaki dalam 1 menit berdasarkan soal, yaitu mengalikan 0,4 dengan 140, berarti subjek sudah mampu menggunakan 1 informasi untuk menyelesaikan masalah (ST.US). Selain itu, subjek dapat mengetahui hubungan dari langkah per menit dengan kecepatan per menit dan menerapkan langkah yang tepat untuk mencari kecepatan dalam meter per menit. Hal ini dapat diketahui dari jawaban subjek yang mengalikan banyak langkah per menit dengan 0,4 meter agar ditemukan satuan kecepatan yaitu meter per menit (ST.MS). Lalu dengan menggunakan cara yang tepat untuk mencari kecepatan dalam meter per menit dan kilometer per jam, berarti subjek telah mampu memadukan beberapa informasi berbeda untuk menyelesaikan masalah (ST. RT).

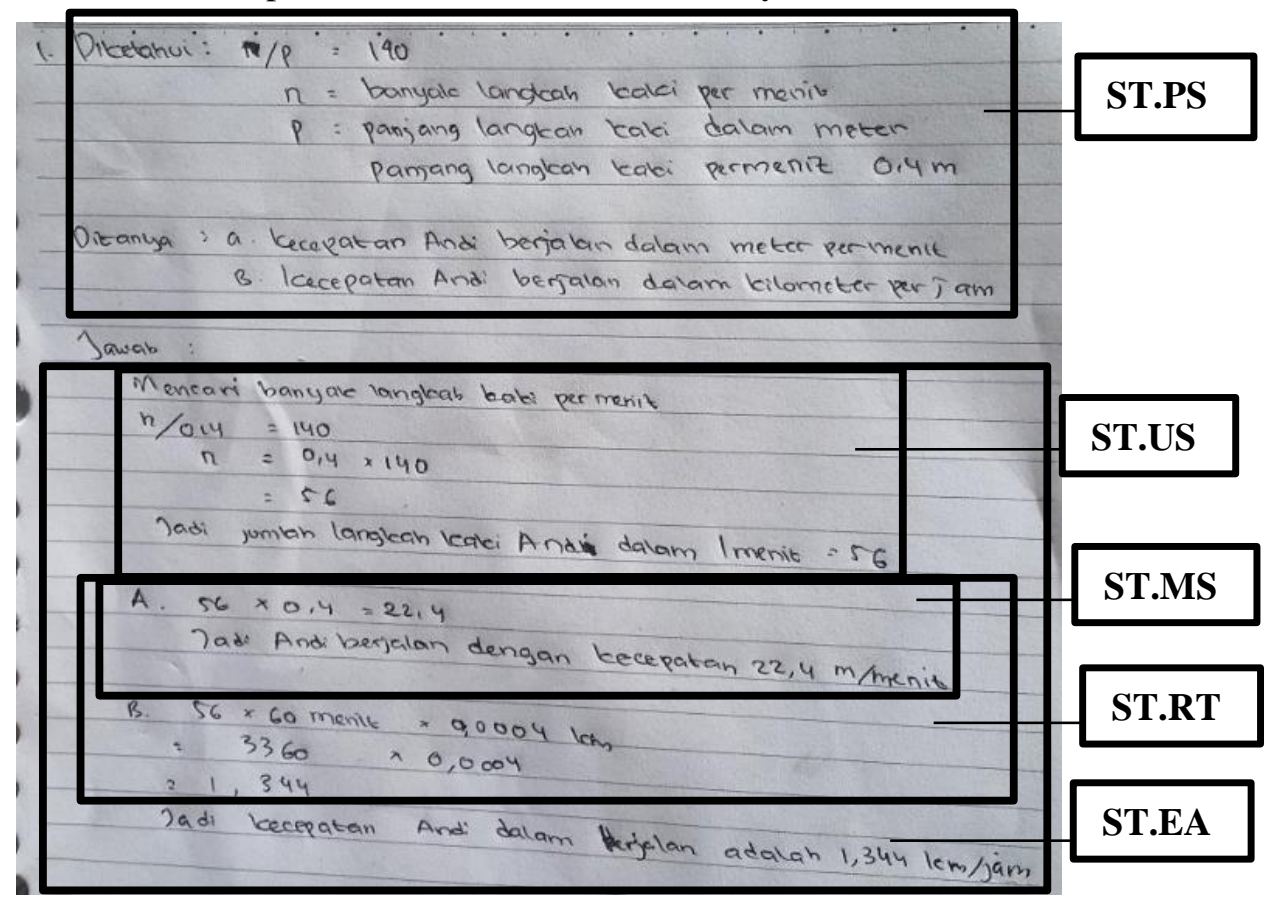

Gambar 3. Hasil Jawaban Subjek ST

Hal ini diperkuat dengan hasil wawancara subjek dengan peneliti yang dilakukan untuk menggali lebih dalam mengenai langkah yang subjek gunakan dalam mencari kecepatan dalam kilometer per jam (ST.HW1). Berikut cuplikan wawancara peneliti dengan subjek.

P1 : kenapa kok dikali 0,0004 kilometer dan 60 menit? Bukannya nanti satuannya jadi $\mathrm{km}$ dikali jam?

ST : karena satuannya yang ditanyakan kilometer per jam, jadi yang atas dikali (ST.HW1) kilometer lalu nanti dibagi 1 jam. 1 menit itu kan sama dengan 1/60 jam. Lalu misal 1 dibagi 1/60 hasilnya kan sama dengan 60. Jadi 0,0004 kilometer dikali 60 menit satuannya nanti sama saja dengan km/jam.

Sehingga berdasarkan jawaban dan hasil wawancara, subjek ST dalam menyelesaikan masalah tersebut dapat dikatakan telah mampu menggunakan dan memadukan informasi-informasi berbeda seperti menempatkan nilai $P$ pada rumus yang telah ditentukan untuk mencari $n$, mengetahui satuan kecepatan dan 
menghubungkannya dengan nilai $n$ untuk mendapatkan hasil dalam meter per menit, dan mencari kecepatan dalam kilometer per jam. Selain itu, subjek juga dapat membuat kesimpulan akhir atau generalisasi dari penyelesaian masalah yang diberikan yaitu kecepatan Andi dalam berjalan adalah 22,4 m/menit dan 1,344 km/jam (ST.EA). Selama pelaksanaan wawancara, subjek juga mampu menjelaskan jawabannya dengan tegas dan tanpa kesulitan.

Sehingga subjek IA dalam menyelesaikan masalah PISA mampu mencapai level Extended Abstract. Hal ini didukung oleh Pesona dalam penelitiannya bahwa siswa yang mampu mencapai level tertinggi adalah siswa dengan kemampuan matematika yang tinggi pula, karena siswa dengan kemampuan matematika tinggi akan mampu memproses informasi yang tersedia dengan lebih mendalam untuk mendapatkan jawaban yang tepat (Pesona \& Yunianta, 2018). Sejalan dengan hal tersebut, Ekawati dkk (Ekawati et al., 2013) mengemukakan bahwa siswa yang memiliki kemampuan memecahkan masalah level extended abstract berarti siswa tersebut mampu memahami masalah dan menggunakan data yang ada serta menghubungkannya dengan proses-proses yang lain untuk menyelesaikan masalah dengan tepat sehingga dari hasil yang diperoleh itu, siswa dapat menggeneralisasikan dan menarik kesimpulan dengan tepat.

\section{Analisis Data Subjek SS (Subjek Kemampuan Sedang)}

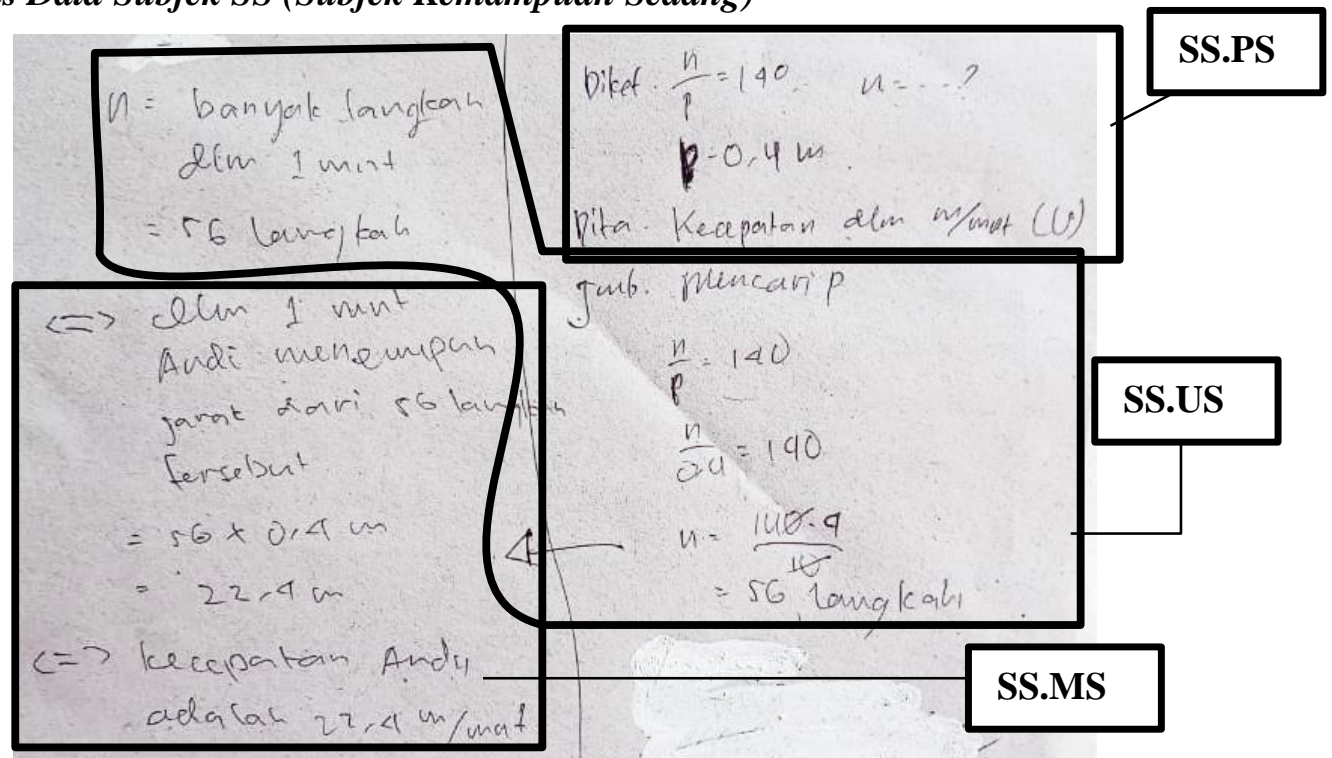

Gambar 4. Hasil Jawaban Subjek SS

Berdasarkan hasil jawaban tersebut, SS mampu memahami soal yang diberikan. Hal ini dapat diketahui dari jawaban SS yang mampu menjelaskan apa saja diketahui dalam soal yaitu panjang langkah kaki Andi $(P=0,4 m)$ dan rumus yang diberikan $\frac{n}{P}=140$, namun untuk yang ditanyakan dari soal, SS hanya menyebutkan satu saja yaitu kecepatan berjalan dalam meter per menit (SS.PS). Dari hal tersebut, berarti SS masih kurang teliti dalam membaca soal, namun masih bisa dikategorikan mampu memahami maksud soal yang diberikan (SS.HW1).

Kemudian dalam menyelesaikan masalah, subjek mampu menggunakan satu informasi untuk menyelesaikan masalah. Hal itu dapat diketahui berdasarkan jawaban SS di atas ketika SS mencari banyak 
Profil Kemampuan Pemecahan Masalah PISA pada Konten Change and Relationship Berdasarkan Taksonomi SOLO, Nanda Putri Wahyuni, Masriyah

langkah per menit (SS.US). Kemudian subjek juga dapat mengetahui hubungan dari langkah per menit dengan kecepatan per menit dan menerapkan langkah yang tepat untuk mencari kecepatan dalam meter per menit. Hal ini dapat diketahui dari jawaban subjek yang mengalikan banyak langkah per menit dengan 0,4 meter agar ditemukan satuan kecepatan yaitu meter per menit (SS.MS). Sedangkan untuk mencari kecepatan dalam kilometer per jam tidak dijawab oleh subjek karena kecerobohan subjek ketika membaca soal. Namun ketika diwawancarai mengenai cara mencari kilometer per jam, subjek SS ternyata mampu menjawab dengan benar (SS.HW2). Sehingga jika subjek SS tidak ceroboh dan menyelesaikan masalah sampai akhir, kemungkinan subjek mampu mencapai level relational. Berikut cuplikan wawancara peneliti dengan subjek SS.

P2 : kamu yakin jawabannya sudah selesai? coba cek lagi pertanyaannya. Apakah benar yang ditanyakan cuma kecepatan dalam meter per menit?

SS : o iya kak. Maaf kurang teliti. Yang ditanyakan kecepatan dalam meter per menit (SS.HW1) dan kilometer per jam.

P2 : bagus. Kalau misal kamu melanjutkan pengerjaanmu, kamu bisa nggk mencari kecepatan dalam kilometer per jam?

SS : bisa kak. Kan tadi sudah ada meter per menit, jadi kalau mencari kilometer per (SS.HW2) jam tinggal dikali dengan 60 per 1000.

Sehingga berdasarkan jawaban dan hasil wawancara yang telah dilakukan, subjek SS dalam menyelesaikan masalah tersebut dapat dikatakan telah mampu menggunakan dan memadukan informasiinformasi berbeda seperti menempatkan nilai $P$ pada rumus yang telah ditentukan untuk mencari $n$, mengetahui satuan kecepatan dan menghubungkannya dengan nilai $n$ untuk mendapatkan hasil dalam meter per menit. Namun karena subjek SS kurang teliti dalam membaca perintah soal dan tidak mencari kecepatan dalam kilometer per jam, SS tidak dapat menyelesaikan soal dengan tuntas. Meskipun dalam hasil wawancara subjek SS kemungkinan mampu mencapai level relational, namun jawaban akhir SS hanya berhenti sampai menemukan kecepatan dalam meter per menit.

Sehingga dalam hal ini, subjek SS dalam menyelesaikan masalah PISA mampu mencapai level Multistructural. Hal ini diperkuat oleh penelitian yang dilakukan oleh Faisal bahwasanya siswa pada level sedang mampu memahami maksud dari soal dan juga mampu merencanakan penyelesaian masalah. Namun siswa mengalami kesulitan saat melakukan proses untuk menyelesaikan masalah sehingga siswa tidak dapat menemukan penyelesaian yang tepat (Faisal \& Maryulianty, 2019). Hal ini didukung oleh Ekawati dkk (Ekawati et al., 2013) yang menyatakan bahwa siswa pada level multistructural mampu menghubungkan beberapa data atau informasi, tetapi terdapat paling tidak satu kesalahan dalam prosesnya sehingga tidak dapat menarik kesimpulan dengan benar. Hasil penelitian yang dilakukan oleh Marisa juga menunjukkan bahwa siswa pada level multistructural mampu menghubungkan beberapa konsep namun tidak bisa menyelesaikannya atau melanjutkan jawaban yang telah dimulai (Marisa et al., 2020). 


\section{Analisis Data Subjek SR (Subjek Kemampuan Rendah)}

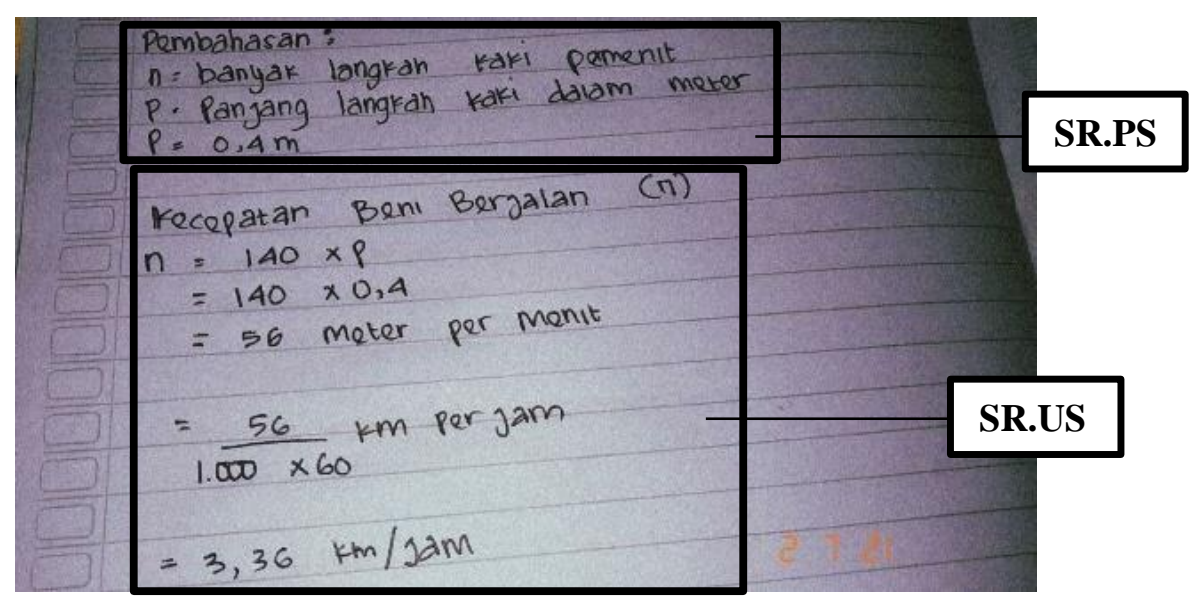

Gambar 5. Hasil Jawaban Subjek SR

Berdasarkan hasil jawaban di atas, SR mampu memahami soal yang diberikan. Hal ini dapat diketahui dari lembar jawaban tersebut bahwa subjek menyebutkan apa yang diketahui yaitu panjang langkah kaki Andi $(P=0,4 m)$ dan rumus yang diberikan $\frac{n}{P}=140$ dan ditanyakan dari soal yaitu kecepatan berjalan dalam meter per menit dan kilometer per jam (SR.PS).

Kemudian pada langkah pemecahan masalah, subjek SR tidak mengalami masalah saat mencari nilai $n$ dengan berdasarkan informasi pada soal, yaitu dengan mengalikan 140 dengan nilai $P(0,4$ meter). Hal ini berarti subjek telah mampu menggunakan satu informasi untuk menyelesaikan masalah (SR.US). Namun pada tahap akhir menemukan nilai $n$, subjek kurang paham mengenai satuan dari $n$ maupun satuan kecepatan yang dicari. Satuan $n$ yang seharusnya langkah per menit, dianggap sama dengan meter per menit (SR.HW3). Sehingga langkah yang digunakan untuk mencari banyak langkah per menit, langsung digunakan untuk mencari kecepatan dalam meter per menit (SR.HW1). Padahal untuk mengubah langkah per menit menjadi meter per menit diperlukan langkah tersendiri. Berikut cuplikan wawancara peneliti dengan SR.

P3 : langkah paling awal yang kamu lakukan untuk menyelesaikan masalah ini apa? (P3.SR)

SR : mencari kecepatan kak. Disini kan diketahui itu ada rumus n per P sama dengan 140. Nah disitu udah diketahui nilai P-nya, jadi untuk mencari kecepatan meter (SR.HW1) per menit tinggal mencari nilai $n$ dari rumus tersebut. Jadi 0,4 dikali 140 sama dengan 56. Diperoleh kecepatan Andi adalah 56 meter per menit

P3 : coba perhatikan lagi rumus yang diberikan. Apakah $n$ itu meter per menit?

SR : n banyak langkah per menit.

P3 : sama nggak banyak langkah per menit dengan meter per menit?

SR : sama aja kak. Kan sama-sama ada jaraknya

P3 : kalo sama, berarti setiap 1 langkah itu jaraknya sama dengan 1 meter dong?

SR : o iya, kak. Berarti nggak sama... hehee 
Profil Kemampuan Pemecahan Masalah PISA pada Konten Change and Relationship Berdasarkan Taksonomi SOLO, Nanda Putri Wahyuni, Masriyah

Berdasarkan hasil wawancara dan jawaban subjek SR, dia langsung mencari kecepatan dalam meter per menit. Padahal satuan yang diketahui $n$ yaitu langkah per menit, bukan meter per menit. Sehingga pengonversian langkah per menit ke kilometer per jam juga belum bisa dilakukan. Namun untuk mengubah meter per menit ke kilometer per jam sudah paham. Dalam hal ini, berarti subjek SR hanya mampu menggunakan satu informasi atau strategi untuk menyelesaikan masalah.

Sehingga subjek SR dalam menyelesaikan masalah mampu mencapai level Unistructural. Hal ini didukung oleh penelitian Ekawati bahwa siswa yang mencapai level unistructural belum bisa menghubungkan apa yang telah diketahui dan ditanya, serta belum dapat menyelesaikan masalah meskipun telah berhasil menggunakan satu konsep penyelesaian (Ekawati et al., 2013). Sejalan dengan itu, Faisal dalam penelitiannya mengemukakan bahwa siswa yang berada di level unistruktural hanya mampu menuliskan informasi yang dibutuhkan untuk menyelesaikan permasalahan dan dengan informasi tersebut siswa dapat menyelesaikan permasalahan dengan menggunakan satu informasi saja, tetapi tidak mampu menyelesaikan masalah yang levelnya lebih rumit dari yang telah berhasil diselesaikan (Faisal \& Maryulianty, 2019). Kemudian dalam penelitian yang dilakukan oleh Putri (Putri \& Manoy, 2013) dapat diketahui bahwa siswa dengan kemampuan matematika rendah mampu mencapai level unistructural, yaitu menggunakan sepenggal informasi dari soal sehingga dapat menyelesaikan masalah dengan sederhana.

Berdasarkan hasil analisis tersebut, berikut ini adalah perbedaan kemampuan pemecahan masalah PISA konten change and relationship pada siswa berkemampuan matematis tinggi, sedang, dan rendah berdasarkan Taksonomi SOLO.

Tabel 3. Perbedaan Kemampuan Pemecahan Masalah PISA Konten Change and Relationship Pada Siswa Berkemampuan Matematis Tinggi, Sedang, dan Rendah

Berdasarkan Taksonomi SOLO

\begin{tabular}{|c|l|l|l|}
\hline $\begin{array}{c}\text { Level } \\
\text { Taksonomi } \\
\text { SOLO }\end{array}$ & \multicolumn{1}{|c|}{ Subjek Berkemampuan Matematis } \\
\cline { 2 - 4 } & \multicolumn{1}{|c|}{ Tinggi } & \multicolumn{1}{c|}{ Sedang } & \multicolumn{1}{c|}{ Rendah } \\
\hline Prestructural & $\begin{array}{l}\text { Mampu memahami informasi } \\
\text { pada soal dengan } \\
\text { menyebutkan yang diketahui } \\
\text { dan ditanya. Sehingga } \\
\text { kemampuan memecahkan } \\
\text { masalah tidak di level ini }\end{array}$ & $\begin{array}{l}\text { Mampu memahami } \\
\text { informasi pada soal dengan } \\
\text { menyebutkan yang } \\
\text { diketahui dan ditanya. } \\
\text { Sehingga kemampuan } \\
\text { memecahkan masalah tidak } \\
\text { di level ini }\end{array}$ & $\begin{array}{l}\text { Mampu memahami } \\
\text { informasi pada soal } \\
\text { dengan menyebutkan } \\
\text { yang diketahui dan } \\
\text { ditanya. Sehingga } \\
\text { kemampuan } \\
\text { memecahkan masalah } \\
\text { tidak di level ini }\end{array}$ \\
\hline Unistructural & $\begin{array}{l}\text { Mampu menggunakan lebih } \\
\text { dari satu informasi atau } \\
\text { strategi untuk menyelesaikan } \\
\text { masalah. Sehingga } \\
\text { kemampuan memecahkan } \\
\text { masalah tidak di level ini }\end{array}$ & $\begin{array}{l}\text { Mampu menggunakan lebih } \\
\text { dari satu informasi atau } \\
\text { strategi untuk } \\
\text { menyelesaikan masalah. } \\
\text { Sehingga kemampuan } \\
\text { memecahkan masalah tidak } \\
\text { di level ini }\end{array}$ & $\begin{array}{l}\text { Mampu menggunakan } \\
\text { satu informasi atau } \\
\text { strategi untuk } \\
\text { menyelesaikan masalah. } \\
\text { Sehingga kemampuan } \\
\text { memecahkan masalah } \\
\text { berada di level }\end{array}$ \\
& $\begin{array}{l}\text { Unistructural } \\
\text { Mampu menggunakan }\end{array}$ & $\begin{array}{l}\text { Mampu menggunakan } \\
\text { beberapa informasi dan } \\
\text { strategi penyelesaian, dan }\end{array}$ & $\begin{array}{l}\text { Tidak mampu } \\
\text { menggunakan beberapa } \\
\text { informasi dan strategi }\end{array}$ \\
\hline
\end{tabular}




\begin{tabular}{|c|c|c|c|}
\hline & $\begin{array}{l}\text { bisa menghubungkannya. } \\
\text { Sehingga kemampuan } \\
\text { memecahkan masalah tidak } \\
\text { di level ini }\end{array}$ & $\begin{array}{l}\text { bisa menghubungkannya, } \\
\text { namun gagal } \\
\text { menyelesaikan masalah } \\
\text { secara tuntas karena hanya } \\
\text { menyelesaikan satu } \\
\text { permasalahan saja. } \\
\text { Sehingga kemampuan } \\
\text { memecahkan masalah } \\
\text { berada di level } \\
\text { Multistructural }\end{array}$ & $\begin{array}{l}\text { penyelesaian untuk } \\
\text { menyelesaikan masalah. } \\
\text { Sehingga kemampuan } \\
\text { memecahkan masalah } \\
\text { tidak di level ini }\end{array}$ \\
\hline Relational & $\begin{array}{l}\text { Mampu memadukan } \\
\text { informasi-informasi berbeda } \\
\text { untuk menyelesaikan } \\
\text { permasalahan dan bisa } \\
\text { melakukan generalisasi. } \\
\text { Sehingga kemampuan } \\
\text { memecahkan masalah tidak } \\
\text { di level ini }\end{array}$ & $\begin{array}{l}\text { Tidak mampu memadukan } \\
\text { informasi-informasi } \\
\text { berbeda untuk } \\
\text { menyelesaikan } \\
\text { permasalahan dan juga } \\
\text { belum bisa melakukan } \\
\text { generalisasi. Sehingga } \\
\text { kemampuan memecahkan } \\
\text { masalah tidak di level ini }\end{array}$ & $\begin{array}{l}\text { Tidak mampu } \\
\text { memadukan informasi- } \\
\text { informasi berbeda untuk } \\
\text { menyelesaikan } \\
\text { permasalahan dan juga } \\
\text { belum bisa melakukan } \\
\text { generalisasi. Sehingga } \\
\text { kemampuan } \\
\text { memecahkan masalah } \\
\text { tidak di level ini }\end{array}$ \\
\hline $\begin{array}{l}\text { Extended } \\
\text { Abstract }\end{array}$ & $\begin{array}{l}\text { Mampu memadukan } \\
\text { informasi-informasi berbeda } \\
\text { dan mampu melakukan } \\
\text { generalisasi. Sehingga } \\
\text { kemampuan memecahkan } \\
\text { masalah berada di level } \\
\text { Extended Abstract }\end{array}$ & $\begin{array}{l}\text { Tidak mampu memadukan } \\
\text { informasi-informasi } \\
\text { berbeda dan juga belum } \\
\text { bisa melakukan } \\
\text { generalisasi. Sehingga } \\
\text { kemampuan memecahkan } \\
\text { masalah tidak di level ini }\end{array}$ & $\begin{array}{l}\text { Tidak mampu } \\
\text { memadukan informasi- } \\
\text { informasi berbeda dan } \\
\text { juga belum bisa } \\
\text { melakukan generalisasi. } \\
\text { Sehingga kemampuan } \\
\text { memecahkan masalah } \\
\text { tidak di level ini }\end{array}$ \\
\hline
\end{tabular}

\section{KESIMPULAN}

Berdasarkan hasil analisis yang telah dilakukan, dapat diperoleh kesimpulan bahwa kemampuan pemecahan masalah PISA konten change and relationship pada siswa kelas IX di SMPN 1 Tarokan yang memiliki kemampuan matematika tinggi, sedang, dan rendah mampu mencapai level yang berbeda-beda berdasarkan Taksonomi SOLO. Siswa berkemampuan matematika tinggi mampu memadukan informasiinformasi berbeda, baik itu informasi dari soal maupun informasi yang berasal dari pengetahuan siswa itu sendiri, dan mampu melakukan generalisasi dengan tepat sehingga dapat mencapai level extended abstract yang merupakan level tertinggi berdasarkan taksonomi SOLO. Kemudian siswa yang berkemampuan matematika sedang mampu menggunakan beberapa informasi dan strategi penyelesaian serta berhasil menghubungkan antar informasi dan mendapatkan jawaban, namun gagal menyelesaikan masalah secara tuntas sehingga siswa tersebut dapat mencapai level multistruktural. Sedangkan untuk siswa yang berkemampuan matematika rendah hanya mampu menggunakan satu informasi atau strategi untuk menyelesaikan masalah sehingga siswa dapat mencapai level unistructural.

Berdasarkan hasil penelitian ini, peneliti memberikan saran kepada guru sebaiknya menggunakan hasil penelitian ini sebagai bahan pertimbangan dalam melaksanakan pembelajaran dan untuk melatih serta menggali pengetahuan siswa agar lebih terampil dalam menyelesaikan masalah PISA sesuai dengan pembelajaran di kelas. Selain itu, kepada peneliti lain, sebaiknya menggunakan hasil penelitian ini sebagai 
Profil Kemampuan Pemecahan Masalah PISA pada Konten Change and Relationship Berdasarkan Taksonomi SOLO, Nanda Putri Wahyuni, Masriyah

bahan perbandingan atau pertimbangan untuk mengembangkan maupun memperdalam penelitian yang berhubungan dengan kemampuan pemecahan masalah PISA pada siswa berdasarkan Taksonomi SOLO pada ranah penelitian yang lebih luas karena kemampuan siswa dalam memecahkan masalah memiliki banyak faktor yang mempengaruhi dan juga dapat diukur dengan lebih banyak cara.

\section{REFERENSI}

Biggs, J. B., \& Collis, K. F. (1982). Evaluating the Quality of Learning The SOLO Taxonomy (Structure of the Observed Learning Outcome). New York: Academic Press.

Ekawati, R., Junaedi, I., \& Nugroho, S. E. (2013). Studi Respon Siswa Dalam Menyelesaikan Soal Pemecahan Masalah Matematika Berdasarkan Taksonomi Solo. Unnes Journal of Research Mathematics Education, 2(2), 101-107.

Faisal, \& Maryulianty, L. (2019). ANALISIS TINGKAT KEMAMPUAN SISWA DALAM MENYELESAIKAN SOAL CERITA SISTEM PERSAMAAN LINEAR TIGA VARIABEL BERDASARKAN TAKSONOMI SOLO. Jurnal Numeracy, 6(1), 153-165. https://doi.org/10.46244/numeracy.v6i1.444

Hasibuan, S. A., Fauzi, K. M. A., \& Mukhtar, M. (2019). Development of PISA Mathematical Problem Model on the Content of Change and Relationship to Measure Students Mathematical ProblemSolving Ability. International Electronic Journal of Mathematics Education, 15(2), 1-9. https://doi.org/10.29333/iejme/6274

Isroil, A., Budayasa, I. K., \& Masriyah, M. (2017). Profil Berpikir Siswa SMP dalam Menyelesaikan Masalah Matematika Ditinjau dari Kemampuan Matematika. Jurnal Review Pembelajaran Matematika, 2(2), 93-105. https://doi.org/10.15642/jrpm.2017.2.2.93-105

Jupri, A., Drijvers, P., \& van den Heuvel-Panhuizen, M. (2014). Difficulties in initial algebra learning in Indonesia. Mathematics Education Research Journal, 26(4), 683-710. https://doi.org/10.1007/s13394-013-0097-0

Marisa, G., Hariyadi, B., \& Syaiful. (2020). Analisis Kesalahan Siswa Dalam Menyelesaikan Soal Operasi Aljabar Berdasarkan Taksonomi SOLO (Analysis of the Errors of Students in completing Algebra Problem Operations Based on SOLO Taxonomy). Jurnal Pendidikan Matematika, 11(1), 77-88. http://dx.doi.org/10.36709/jpm.v11i1.9971

National Center for Eduction Statistics (NCES) USA. (2013). PISA 2012 Data Tables, Figures, and Exhibits. http://nces.ed.gov/pubs2014/2014024_tables.pdf

NCTM. (2000). Principles and Standards for School Mathematics. USA: The National Council of Teachers of Mathematics, Inc.

OECD. (2019). PISA 2018 Assessment and Analytical Framework. Paris: OECD Publishing. https://doi.org/10.1787/b25efab8-en

Pesona, R. I., \& Yunianta, T. N. H. (2018). DESKRIPSI KEMAMPUAN MATEMATIKA SISWA DALAM PEMECAHAN MASALAH SISTEM PERSAMAAN LINEAR DUA VARIABEL 
BERDASARKAN LEVEL. GENTA MULIA: Jurnal Ilmiah Pendidikan, IX(1), 99-109.

Putri, L. F., \& Manoy, J. T. (2013). Identifikasi Kemampuan Matematika Siswa Dalam Memecahkan Masalah Aljabar di Kelas VIII Berdasarkan Taksonomi Solo. MATHEdunesa, 2(1), 29-30.

Ratri, A. K., \& Setyaningsih, N. (2020). Analisis Literasi Matematika Terhadap Kemampuan Menyelesaikan Soal Berorientasi High Order Thinking Skills. Prosiding Konferensi Nasional Penelitian Matematika Dan Pembelajarannya (KNPMP) V 2020, 162-175. http://hdl.handle.net/11617/12213

Schleicher, A. (2019). PISA 2018 Insights and Interpretations. OECD Publishing.

Seifi, M., Haghverdi, M., \& Azizmohamadi, F. (2012). Recognition of Students' Difficulties in Solving Mathematical Word Problems from the Viewpoint of Teachers. Journal of Basic and Applied Scientific Research, 2(3), 2923-2928.

Silwana, A., Subanji, S., Manyunu, M., \& Rashahan, A. A. (2021). Students' Responses Leveling in Solving Mathematical Problem Based on SOLO Taxonomy Viewed from Multiple Intelligences. Indonesian Journal on Learning and Advanced Education (IJOLAE), 3(1), 1-16. https://doi.org/10.23917/ijolae.v3i1.10528

Siswono, T. Y. E. (2008). Model Pembelajaran Matematika Berbasis Pengajuan dan Pemecahan Masalah untuk Meningkatkan Kemampuan Berpikir Kreatif. Surabaya: Unesa University Press.

Sugiarti, L. (2018). Kesulitan Siswa dalam Menyelesaikan Soal Operasi Bentuk Aljabar. Prosiding Seminar Nasional Pendidikan Matematika Etnomatnesia, 323-330.

Wijaya, A., van den Heuvel-Panhuizen, M., Doorman, M., \& Robitzsch, A. (2014). Difficulties in solving context-based PISA mathematics tasks: An analysis of students' errors. Mathematics Enthusiast, $11(3), 555-584$. 